\title{
Partners in Advocacy: Lobbyists and Government Officials in Washington
}

\author{
Christine Mahoney, University of Virginia \\ Frank R. Baumgartner, The University of North Carolina at Chapel Hill
}

One of the most important demonstrations of power in Washington is the ability to recruit sitting government officials to become active proponents of one's position. Many have suggested money is the key: Campaign contributions buy friends, access, and perhaps even policy activism. We provide an alternative view based on a deceptively simple observation: Lobbyists rarely lobby alone. We show empirically that government policymakers respond to the overall structure of conflict, not the resources of individual lobbying groups. Our project is based on in-depth interviews with over 300 policy advocates and systematic information on each of more than 2,000 advocates playing a significant role in a random sample of 98 policy issues in the United States federal government from 1999 to 2002.

$\mathrm{C}$ onsider a government official deciding on where to invest time and resources. ${ }^{1}$ Many lobbyists, staff members, colleagues within government, and others urge involvement in this or that issue. They know the officials' ideological predispositions, the mission of the organization they lead and the current political context, so they tailor their proposals to be things that the official supports and which may be feasible. The official can easily sign a letter or express support in a passive manner, but when will she take the initiative to become a leader at the national level on an issue? She can choose only a few issues, and the choice comes from among many attractive alternatives. She is likely to invest resources where she can predict success. Therefore, she will become active if she sees a powerful set of actors mobilized and committed to the cause.

We seek to answer this question: what determines if a government official becomes a leader on a national policy debate? We are not concerned with passive support, such as signing onto a "dear colleague" letter or issuing a single press release, but rather becoming a true leader, recognized by other policy advocates as being one of the leading advocates for a policy position. We demonstrate that government officials are rational actors, responding to the likelihood of success in achieving their policy goals. In particular, they invest their time where they see impressive lobbying sides. Where they see a great deal of lobbying resources supporting their preferred policy position, and where they see other prominent government officials leading the way, they join a bandwagon. Where they see extreme partisan conflict, too much news coverage, or the demands of individual interest groups not backed up by an extensive supporting side, they demur. By demurring, they simply sit out the issue, perhaps expressing support and moral encouragement if they agree with the lobbyist requesting action (or simply want to appear to be on their side) but eschewing a leadership position on the issue. They become leading advocates on the national stage when they see the right conditions. The right conditions are lobbying sides including

Christine Mahoney is Associate Professor of Politics \& Public Policy at the Frank Batten School of Leadership \& Public Policy and the Woodrow Wilson Department of Politics at the University of Virginia, Charlottesville, VA 22904-4893. Frank R. Baumgartner is the Richard J. Richardson Distinguished Professor of Political Science at The University of North Carolina at Chapel Hill, Chapel Hill, NC 27599-3265.

1. Support for the larger project from which this analysis was taken came from Penn State University and the National Science Foundation through awards SBR 0111224 and SBR 9905195. An online appendix with robustness tests for our statistical models is available at the "Supplements" link in the online edition. Data used in the article and the replication do-file are available at http://www.unc.edu/ fbaum/books/lobby/documentation.html. Note that because of confidentiality promised to our interviewees, we have deleted variables from this public-release database that would allow identification of individual organizations. We have retained, however, all aggregated variables and others that do not allow individual actors to be identified.

The Journal of Politics, volume 77, number 1. Published online December 16, 2014. http://dx.doi.org/10.1086/678389

(C) 2015 by the Southern Political Science Association. All rights reserved. 0022-3816/2015/7701-0016 $\$ 10.00$ 
prominent officials at high levels of the government as well as extensive lobbying resources mobilized by outside groups.

The issue of what determines the active involvement of government officials is an important one, as it is the best predictor of success in the policy process. Baumgartner and colleagues $(2009,208)$, in their extensive study of lobbying success and failure, noted that the lobbying side with more high-level government actors was successful $78 \%$ of the time. By contrast, the side with more PAC contributions won just $50 \%$ of the time. We go into greater detail here, using the same data base from the most extensive study of lobbying done in recent years, to focus on a simple question: What determines the mobilization of government officials to become active policy advocates for a given policy position?

\section{GOVERNMENT OFFICIALS AS ALLIES IN ADVOCACY}

Elected officials are often portrayed as the objects of lobbying efforts, but they are also advocates for various policy positions. Each president seeks to push a legislative agenda. Cabinet secretaries mobilize to promote policy changes within their jurisdictions, often coming into conflict with other government officials. The Environmental Protection Agency may enforce regulations against federal agencies such as the Defense Department. The Surgeon General or the Secretary of Health and Human Services may launch a health campaign whereas the Department of Commerce or Agriculture may have a different position on the issue, as was seen in smoking and tobacco issues over the years.

Of course, the policy role of government officials has long been recognized, from the goal of influence in Washington that motivates elected officials (see, e.g., Fenno 1973; Kingdon 1989; Mayhew 1974) to the literature on policy subsystems since the turn of the twentieth century (see, e.g., Bentley 1908; Cater 1964; the review in Baumgartner and Leech 1998), with one classic study going so far as to refer to groups as mere "service bureaus" to Members of Congress (Bauer, Pool, and Dexter 1963). On the other hand, some authors have focused on lobbying by individual interest groups taken out of their context and have presented their activities as those of "outsiders" seeking to influence relatively inert "insiders" (e.g., Austen-Smith 1993; Austen-Smith and Wright 1994; Becker 1983; Bender and Moe 1985). Indeed, much of the literature attempting to assess the potential power of PAC contributions to sway congressional votes adapts this approach (see, for examples, Grenzke 1989; Wright 1985, 1990; others reviewed in Smith 1995). Clearly, authors such as Heclo (1978), Kollman (1998), Ainsworth (1993, 1997), Sabatier (1988), and Heinz et al. (1993) have noted the active roles that government officials play in iron triangles, issue networks, advocacy coa- litions, and other policymaking systems. Our findings suggest that these approaches are much more in tune with the process of advocacy than any approach that treats the interest group as an "outsider" and ignores the active policy advocacy role of government officials. Baumgartner and Leech (1998, 13-17) identified the decontextualized study of interest groups lobbying one legislator at a time, often measured through PAC contribution, as an "area of confusion" in the literature, as the empirical results are so widely scattered and often contradictory. In this article, we suggest that the influence of groups can only be assessed when the context of lobbying, namely the mobilization of other groups on the same issue, is taken into account.

While the literature on lobbying developed with a view of interest groups mostly "outside" government trying to affect the behavior of seemingly neutral officials, wholly separate literatures focusing on policymaking treated these officials in a more realistic manner (for examples, see Aberbach, Putnam, and Rockman 1981; Fenno 1973; Kingdon 1989, 1995; Mayhew 1974, 1991; Price 1978; Redford 1969). Policy advocacy can and very often does come from actors within government as well as from those on the outside. Speeches, "dear colleague" letters, and various efforts to persuade are part of the arsenal of government officials, but they cannot be used by lobbying groups outside of government. By the same token, interest groups have resources such as money, information, membership, and the ability to mobilize the public that insiders may not control. There are therefore strong inducements to cooperate. Even social movement scholars, long focused on studying those protesting against state power, recognize that social movement actors often have tight links to people within government. Banaszak's (2010) analysis of the prominent roles of high-level government employees, particularly in the Justice Department, as leaders of the women's movement suggests that alliances among outsiders and insiders are not only typical of lobbying campaigns as we discuss here, but were central in the development of one of the most significant social movements of the twentieth century.

Of course government officials of all types regularly take positions on controversial issues; this is what it means to be a political leader. In doing so, these insiders work hand in hand with groups from the outside. Conceiving of lobbying groups and government officials as parts of collective efforts to move public policy in one direction or another raises the question of how these teams are put together. How do interest groups recruit government officials to join their cause? Why do some lobbying efforts mobilize large numbers of government officials actively to support the cause, while others can recruit no one or just a few officials? 
This approach is central to DeGregorio's (1997) study, Networks of Champions. Based on extensive fieldwork in the U.S. House of Representatives, she notes that outside "Advocates" work with inside "Champions" to push legislation forward. Rank-and-file members of Congress are brought along by a network of leaders including, in particular, other elected officials who assume leadership positions on the issue. Outside groups, in this view, require a powerful inside champion and work hard to find them. She quotes longtime Washington insider Charles E. Walker on the importance of finding a "good horse": “. . . if advocates are to acquire power on Capitol Hill, they need allies inside the institution who are willing to work with them in promoting the issues the advocates care about. Second, not just any ally will do. The advocates need to be selective about who they choose to take up their causes" (23). Our study is about how coalitions of outside groups succeed in recruiting these allies.

In a fundamental study that promotes a new way of thinking about this same issue, Hall and Deardorff (2006) introduce the concept of the "legislative subsidy." In order to gain the legislative allies they need, groups target members of Congress who share their policy goals and offer to help them with legislative information, staff time, and other resources to make it easier for the congressional office to take on a leadership role in the policy fight. Members of Congress want to have legislative accomplishments and to achieve their ideas of "good public policy" but of course have limited resources and more concerns than they can take up in the time available. By subsidizing their congressional allies, outside interests encourage them to "take up the fight" for the common cause. In the absence of a subsidy, the fear is not that the congressional office will oppose the group, but that it will spend its time and effort on some other issue. So the prize that lobbyists are seeking in this perspective is attention and engagement on "their" issue rather than some other one. Given the scarcity of time and attention on Capitol Hill, participation or engagement, not votes, is the key goal of a lobbyist. Hall and Deardorff's work is important because it makes sense of so many anomalies in the literature, including why we regularly observe lobbyists working so closely with people who already agree with them rather than targeting fence-sitters or those who may be opposed. Their conception of the links between insiders and outsiders is also much more realistic than many previous studies because it recognizes the cooperative nature of many lobbyist-official interactions and the different resources that actors inside and outside of government bring to the table. Insiders have democratic legitimacy, public visibility, access to other insiders, and sometimes control over proce- dural variables. Outsiders may have money, large memberships, links to the community, technical or political information, and other resources. DeGregorio (1997) and Hall and Deardorff (2006) make clear that inside-outside coalitions are fundamental to understanding legislative lobbying, and we build on their work here.

Our study differs in an important way from that of Hall and Deardorff, however, because we use a different unit of analysis. They model the one-to-one linkage between a group and a single elected official. We model the aggregate relation between groups and officials. While our results are consistent with their ideas, the shift in levels of aggregation makes an important difference. Exploring the linkages between their individual-level study and our aggregate-level results will certainly require further research.

Leech and Baumgartner (1998) documented a fact widely understood in Washington but rarely discussed in the literature: Groups can easily identify supportive and hostile congressional committees, executive agencies, and other government units. In a survey of lobbyists conducted in the late 1990 s, $83 \%$ could name a supportive congressional committee ( $44 \%$ could name three different ones) and 75 to $80 \%$ could mention an executive agency or another federal government institution supportive of their position on a particular policy issue. Hostile official actors also abound: $64 \%$ could identify a hostile congressional committee; $60 \%$ a hostile executive agency, and $68 \%$ another type of federal institution hostile to the group's policy position on the issue at hand. In fact, working in tandem with government allies was the norm, as fully $70 \%$ of the lobbyists they surveyed reported asking members of Congress or White House staff to contact other government officials with regards to the policy issue on which they shared an interest. This number reached $89 \%$ for corporations and unions and was over $80 \%$ for all organizations with more than five lobbyists on staff (Leech and Baumgartner 1998, 228-30). Clearly, lobbyists are not on the outside looking in. Especially for those with a significant lobbying presence in Washington, they are engaged with their legislative allies within government and usually working against a constellation of forces that also includes both insiders and outsiders.

Baumgartner and Leech (2001) showed another aspect of the Washington lobbying process that we explain better here: the tendency for policy issues to attract either very few or a vast number of lobbyists. They showed a "fat tailed" distribution of lobbying across a sample of 136 randomly selected issues, using Lobby Disclosure Reports. These data suggested a puzzle: a few issues at any given moment generate the mobilization of hundreds or thousands of lobbyists, but the vast majority interest just a small number. If 
we conceive of Washington policymakers as being attuned to the likelihood of success, and closely watching the actions of those around them, then it makes sense why many do not bother to mobilize on those issues where few others are active, but why so many feel compelled to become active on those few issues where passage seems more than a remote possibility.

Heaney and Lorenz (2013) conducted a large study based on hundreds of personal interviews with lobbyists and government officials, and they note that groups are more influential when they are positioned centrally within a network of lobbyists. That is, officials take cues from the overall distribution of groups active on an issue, and those groups that are positioned at the core of the network are seen by others as having more influence. Their work, based on an extensive set of interviews, shows clearly that the influence or effectiveness of Group A is determined in part by the actions of Groups B, C, and D. It makes intuitive sense to believe that the overall constellation of groups mobilizing for and against a policy proposal would matter more than the actions of any single group, but scholars have often focused on single groups taken out of this context because of the relative difficulty in gathering data on the entire constellation of groups active on a given issue. Such studies require data such as that gathered by Heaney and Lorenz (2013) for one issue or what we have here for a larger sample (see also Carpenter, Esterling, and Lazer 1998; Heinz et al. 1993; Lauman and Knoke 1987).

\section{Recruiting a Champion}

Lobbyists are not lone actors trying to influence officials in a vacuum; they are embedded in an issue context that involves other actors who agree with them and still others who do not. What would make an official take on a particular policy initiative? Rather than consider the actions or demands of any single interest group, they might be more concerned about the overall lay of the land: the position of the president and other significant political actors and the scope of mobilization from those who support the position the official shares. Public salience and the degree of partisanship might play a role: heavily partisan issues might be unattractive since they could result in negative coverage. Alternatively, extremely partisan issues might draw a policy maker to the fight to make sure their party's side of the story is heard. And public salience, while expected on any issue where major government officials are active, may itself be a sign of too much controversy. So we expect government officials to be attracted to issues where they see large mobilizations already present and repelled from those where media salience and partisanship are too great. Here is an item they do not care about: the position of individual lobbying organizations. No matter what the level of PAC contributions, lobbying expenditures, or purported mobilizational clout of any individual interest group, government officials will not become leaders on issues based on the pleas of individual lobbyists. They care about the overall issue context, not the actions of any single interest group. Of course, the overall distribution of mobilization is made up of the sum of the actions of individual groups. Therefore, our results appear to be completely consistent with those of Hall and Deardorff (2006) regarding individual groups' efforts to mobilize individual legislators. Looking at the aggregate patterns rather than the microprocesses provides a different perspective on the same issue.

There should be no surprise that government officials take into account the full range of mobilization when deciding where to allocate their time rather than looking only at the actions of one group. The surprise comes in that the literature on lobbying had not focused on this; the tendency to study single lobbyists in isolation rather than as part of a collective is due to the difficulty in gathering data on those collectives. A survey of interest groups will not do; one has to draw a sample of issues as we have done and then study all those involved in the issue. The rich contextual information that we collected provides a vastly different and much more realistic view of the forces that a government official might take into account. The search for a single actor whose behaviors affect all the others is akin to asking who is steering a boat awash in the currents of a raging river.

\section{A MODEL PREDICTING GOVERNMENTAL ALLIES}

Our empirical approach is extremely simple. We propose a model predicting the number of governmental allies actively promoting a given policy position. The model has three sets of variables. First are individual resources including measures of monetary (lobbying expenditure), personnel (number of in-house lobbyists, number of hired lobbyists, and number of former policymaker lobbyists) and election-related resources (PAC spending) for each interest group active on the issue. We expect little to no impact of these individual-level measures because we expect government officials to look beyond only individuals and consider the overall constellation of actors involved, including other government officials. In this way our expectations differ most dramatically from previous studies.

Our second set of variables focuses on the collective resources and composition of the lobbyist's allies and their opposition. A "side" includes everyone fighting for the same policy outcome; they may be working hand in hand, or they may not even know the other is working on the issue, but 
they are fighting for the same policy goal. There are often two sides to a debate (especially as the issue nears a legislative vote and the parties coalesce), but any number of sides may be active, and in our dataset, the number of sides ranges from one to seven, with two being by far the most common number (see Baumgartner et al. 2009, 57-61). We refrain from calling these sides "coalitions" since we want to emphasize the often uncoordinated nature of their activities. We look at three characteristics of each side: first, its collective material resources (similar to the material resources assessed for individual interest groups but collectively for all members of the side); second, its composition (number of members and inclusion of actors of different types, including government officials); and third, intent (whether the side supports the status quo or is pushing for policy change). We expect government officials to respond favorably to those sides that have the most resources, include prominent government officials, and seek to change the status quo. Finally, we incorporate measures of the strength of the opposition into our model. Since policy makers survey the entire issue landscape, it is not enough to know who is on one side, and how strong that side is, but also who they are up against. Controlling for the strength of the opposition, government leaders want to be involved in strong sides. With limited time but many policy goals, they seek to invest in those policy initiatives where victory may be possible. That is, we assume that these officials seek to achieve policy successes. As they have many goals, the question of concern is on which issue they should invest their scarce time and energy. Our expectation is that they will invest where they think they can win.

Our third set of variables concerns the issue itself: media salience and partisanship. Controlling for other factors in the model, elected officials may seek to avoid those issues with "excess" public salience, as this could be a sign of controversy. Naturally, we might expect that issues with high involvement of leading government officials or large mobilizations by interest groups would generate some news coverage. Controlling for these factors in the same model, we expect news coverage to have a negative effect. Similarly, controlling for other factors, we expect officials to be loath to become involved in issues that have taken on highly partisan overtones.

In sum, we consider characteristics related to the lobbyists, the sides, and the issues themselves. Such a multilevel analysis will show that government officials look at the nature of the issue and the overall constellation of forces mobilized for and against when making their decisions about where to invest their effort. Controlling for these factors, we expect to find no significant relationship between individual lobbying resources and official conduct. Put another way, individual lobbying organizations cannot "buy friends" in Washington, controlling for the actions of others. The mobilization of government officials simply does not come that cheap. By contrast, we do expect that officials will be sensitive to the overall distribution of material resources mobilized on the issues that are presented to them. They do indeed want to be part of a winning side, and they do indeed like to work on issues where they expect to win. And money matters.

We summarize our expectations with the following hypotheses:

Hypothesis 1: The number of government officials mobilized on a particular side is unrelated to the material resources of any individual lobbying organization.

Hypothesis 2: The number of government officials mobilized on a particular side is positively related to the aggregate material resources of those lobbying on that side.

Hypothesis 3: The number of government officials mobilized on a particular side is positively related to the presence of prominent government officials (such as the White House or the party leadership in Congress) also active on that side.

Hypothesis 4: The number of government officials mobilized on a particular side is negatively related to media salience.

Hypothesis 5: The number of government officials mobilized on a particular side is negatively related to partisanship.

\section{DATA AND EMPIRICAL APPROACH}

We use data from the "advocacy and public policymaking" project (Baumgartner et al. 2009). The details of this project are explained in detail in the book just cited and the associated web site (http://lobby.la.psu.edu). In brief, a large team of investigators conducted over 300 interviews with Washington policy advocates and collected publicly available information on a random sample of 98 policy issues. The issues reflect a random assortment of cases on which lobbyists were active during the last two years of the Clinton administration and the first two years of the George W. Bush administration (1999 to 2002). Note that the sampling was weighted by the level of lobbying, so the resulting set of issues accurately reflects the objects of lobbying activity in Washington. Once an issue was chosen (based on a lobbyist explaining "the most recent issue dealing with the 
federal government" on which they had been active), subsequent interviews were conducted with leading advocates on various sides of the debate, and research assistants conducted an intensive compilation of publicly available documents, including: congressional floor statements, bills, congressional testimonies, media stories, organizational press releases, organizational directories, among other items. Further research included enumerating all the important players on the debate and gathering exhaustive information concerning their lobbying expenditures, PAC contributions, and other material resources as described in more detail below (and made available on the project web site). The enumeration of all the important players on the sample of policy issues also includes, of course, a number of government officials. Thus we know who was involved on one side or the other. Forty-one percent of these advocates were government officials, so we can look empirically and with a generalizable sample of issues covering the full range of lobbying activities in two presidencies to determine the correlates of mobilization of public officials as advocates. While all issues included at least one outside interest (since we started with an interview with a lobbyist), the number of government officials identified as active proponents of a position in each case is, we believe, an accurate reflection of their presence in the Washington policy process. This number ranges from zero to 25 .

Issues were selected at random and therefore include a broad range of topics of government advocacy from the highest visibility issues generating intense activity by scores of powerful groups and leading to public statements and news coverage of major political figures to the most mundane and obscure efforts to amend regulations, Medicare payment schedules, and other smaller lobbying topics. Respondents identified the major actors working on the issue, including both those working with them in a formal or informal coalition as well as those working independently but toward the same goal. They also identified those active in leading any opposition that might have been present. Major participants then, are those actors perceived by the players involved to be the primary representatives of various policy positions on an issue. From these interviews and subsequent reviews of publicly available information such as congressional statements, hearings, organizational web sites, and news reports, we compiled complete lists of the major participants on each of the issues. Further, each was identified with what "side" of the issue they were on: pushing for a reform, protecting the status quo, or for another objective. Sides were defined as actors who shared the same objective. This led to the identification of 2,221 actors active on 214 sides across the 98 issues. For each actor, we know their material resources, their goals, and the nature of their allies and their opponents. Such a wide-ranging data-collection process allows the investigation of many fundamental issues of who wins and who loses in Washington, and many of these were explored in a recent book-length treatment (Baumgartner et al. 2009) as well as a cross-national comparison of the United States and the European Union (Mahoney 2008). One of the strongest correlates of policy success was the presence of high-level government allies. Here, our focus is on what it takes to recruit such allies.

The key element of the data collection and design associated with this project that sets it apart from previous studies and makes it particularly amenable to the analysis we want to do here is that the sampling design was clustered on issues. We have enumerated not a sample of lobbyists and allies, but a census of all those playing important roles on each of the 98 issues. While we conducted interviews with only 300 -some of the $2,000+$ policy advocates identified, we have gathered systematic information about all of them. Thus, we can look very clearly at the relative mobilization of each side of the lobbying equation, across a generalizable sample of policy issues. Our data analysis is as simple as our data-collection process was complicated. We estimate the number of government officials on a side, with our independent variables being measures of individual group characteristics, the characteristics of the sides within which those groups are nested, and the characteristics of the issues within which those sides are nested.

Finally, we should note that our data were collected simultaneously; that is, we did not record the precise timing of when an advocate became involved in the issue. In the analysis below, we use the number and resources of the lobbying organizations mobilized on the issue to predict the number of government officials who take on the fight. It is possible that lobbyists are responding to the presence of the government officials rather than the other way around. Like government officials, lobbyists may prefer to be involved in issues with a high probability of success, and so they may gear their efforts toward issues that appear to have already mobilized powerful officials. On balance, however, we think the preponderance of cases fall in the category where the groups come first, and the government allies afterwards. Our reason for confidence in this is both theoretical, that gaining government allies is the goal of much lobbying, and qualitative. Our experience in doing the interviews convinced us that groups are typically going after the government officials, not the other way around. There may, of course by occasional counterexamples or some groups that are mobilized by officials or where the entire community was affected by an outside event. While 
it can happen both ways, and it is difficult empirically to separate this out, our interviews with hundreds of lobbyists and officials suggest that the bulk of the action conforms to the statistical model we present below.

\section{INDIVIDUAL AND COLLECTIVE RESOURCES}

If journalists and academic analysts are quick to look for the impact of individual lobbyists in Washington, policy makers are looking at a bigger picture. And they may be very different pictures indeed. Our dataset consists of information of 1,244 interest groups active on 214 sides. If we look at the individual groups, we find that half the lobbyists spent less than $\$ 60,000$ on lobby-related expenditures. Of course the distribution of spending is quite skewed, and two organizations spent over $\$ 9$ million (this distinction goes to the U.S. Chamber of Commerce and the American Medical Association). Looking at the sides rather than the individuals paints a different picture, however: $95 \%$ of advocates are part of a side which spent at least $\$ 90,000$, and many sides expend millions, with the maximum being $\$ 41$ million. What was this well-heeled side, and what were they fighting for?

The wealthy side that reported a whopping $\$ 41$ million on its lobby disclosure reports was opposed to President Clinton's Patient's Bill of Rights. The group included heavy hitters such as the U.S. Chamber of Commerce, Blue Cross/ Blue Shield, the Business Roundtable, Ford, General Motors, and Aetna, all interests with significant resources to use in a lobbying fight. However, there were groups that spent much less: The Health Benefits Coalition reported a total lobbying expenditure of $\$ 60,000$, and the Associated General Contractors of America reported a total lobbying expenditure of just $\$ 80,000$. Supporting the Patient's Bill of Rights was a set of interests that reported collective spending of \$20 million. This side also included groups that spent relatively little, such as the American Association of Maxillofacial Surgeons, the Consumers Union, and Families USA, but it also included the single biggest spender, the American Medical Association, which reported $\$ 9$ million in lobbying expenditures during the period of study. Two things are of interest: first, the huge mobilization of $\$ 41$ million on one side was met by a huge countermobilization, $\$ 20$ million. Second, each side was internally heterogeneous; many poor groups were on the wealthier side, and the single wealthiest group was on the poorer side of the debate.

The Clinton administration's proposal to offer Permanent Normal Trade Relations with China similarly generated massive lobbying by heterogeneous collections of interest groups. Opponents worked to block the deal for a range of reasons and came from many sectors: Friends of the Earth, the Sierra Club, the Humane Society of the United States, the International Campaign for Tibet, Public Citizen, the Veterans of Foreign Wars, as well as the AFL-CIO and the UAW. In spite of this big collection of heavy hitters, this was the "poorer" side, with a collective lobbying expenditure of $\$ 4.5$ million. On the other side, with collective spending of $\$ 11$ million, were groups including The Business Roundtable (which spent \$5.6 million) and the American Electronics Association (\$2 million), but also including groups that spent relatively little, such as the Sunkist Growers, $(\$ 60,000)$ and the American Soybean Association $(\$ 80,000)$. Table 1 reports the basic statistics on the resources of individual advocates and the collective resources of the sides for which they are fighting.

The heterogeneity of resources of those organizations that mobilize to support or oppose any given legislative proposal ensures mathematically that it will be difficult to find support for any model that seeks to establish an empirical linkage between individual resources or spending and the mobilization of government officials. The officials may mobilize because they support one group, but they automatically become the allies of all the others who are supporting the same goal (see Baumgartner et al. 2009, Chap. 10). Across the set of issues that comprise the sample we study here, heterogeneity of sides is the rule, not the exception. Sides are heterogeneous because complex public policies have a great variety of impacts on diverse constituencies across the country. Strange bedfellow sides are put together not necessarily by strategic planning by wealthy groups seeking a "pretty face" for their lobbying efforts, but because the policies have diverse impacts on multiple different groups in society.

Figure 1 demonstrates the great heterogeneity of group resources mobilized on our sample of issues. It shows, for two measures of group resources, the relation between individual resources and those of the associated side. Baumgartner and colleagues $(2009,211)$ showed that the correlations across 13 different measures of resources ranged from 0.05 to 0.31 . The figure illustrates this with PAC contributions and our overall index of material resources.

\section{WORKING WITH ALLIES, OR "WHO DOESN'T LIKE THE DALAI LAMA?"}

Groups work closely with their legislative allies. Baumgartner et al. (2009, 195-96) give a sense of the "team-like structure" that unites interest groups and their legislative champions on certain issues. Modern whipping organizations rely not only on committed members to round up votes, but they are often articulated with interest-group partners who work in ways that members cannot. Outsiders and insiders 
Table 1. Resources of Individual Lobbyists and Sides

\begin{tabular}{lcccc}
\hline \multicolumn{1}{c}{ Variable } & Mean & Standard Deviation & Minimum & Maximum \\
\hline Total allies & & & & \\
Total opponents & 6.26 & 5.51 & 0 & 25 \\
Individual Resources & 3.80 & 4.26 & 0 & 26 \\
\hline In-house lobbyists & & & 0 & 1 \\
Hired lobbyist & 0.33 & 0.47 & 0 & 1 \\
Lobbying expenditure & 0.26 & 0.44 & 0 & $\$ 9,780,000$ \\
Covered officials & $\$ 353,046$ & $\$ 1,188,889$ & 0 & 15 \\
PAC spending & 0.21 & 0.90 & 0 & $\$ 12,900,000$ \\
Aggregate Resources & $\$ 371,000$ & $\$ 1,253,629$ & & 30 \\
In-house lobbyists & & & 0 & 19 \\
Hired lobbyist & 5.88 & 5.50 & 0 & $\$ 41,800,000$ \\
Lobbying expenditure & 4.46 & 4.14 & 0 & 29 \\
Covered officials & $\$ 5,691,829$ & $\$ 7,583,802$ & 0 & $\$ 67,500,000$ \\
PAC spending & 3.83 & 6.00 & 0 & 3.80 \\
Resources index & $\$ 6,782,498$ & $\$ 12,300,000$ & -0.99 & \\
\hline
\end{tabular}

Note- $\mathrm{N}=2,221$ for all variables.

together decide who might be the most effective contact for a given target and what argument might be most compelling to that individual, and they all share information such as vote tallies. Several examples from our issues illustrate the teamwork, division of labor, and coordination that is common among outsiders and insiders who share a policy goal.

An advocate active on PURPA reform (the Public Utilities Regulatory Provisions Act) noted the long hours spent with their allies: "What is now S. 2439 really started during the House debate last summer. We realized we were going to lose and so the folks from biomass and I went over and started talking with Feinstein and Kennedy's people. And we've literally spent untold hours in one little conference room in Kennedy's office hashing through some of this stuff, again and again and again. Most recently we did about six hours three weeks ago."

An advocate on Water Infrastructure reform discussed not only his key allies, leading a caucus they created, but also the scale of support those key allies helped mobilize: "We created a water infrastructure caucus and we got more than eighty members to sign up for it. We had the chairman and ranking members of the Water Resources and the Health subcommittees in Energy and Commerce and Transportation Infrastructure. They were the founders of the water infrastructure caucus. All their names began with B so we called them the killer Bs. Sometimes you have to use humor to get interest in this kind of thing."

The battle over Permanent Normal Trade Relations (PNTR) with China mobilized some of the heaviest hitters in American politics. One major business organization sup- portive of the measure gave this remarkable explanation of the degree of cooperation and planning among insiders and outsiders:

Periodically, we'd bring the whole coalition to the Hill for a rally with the champions [e.g., the members of Congress with whom they were working] and then there would be a period where these two guys [e.g., their highly visible paid lobbyists, major Washington power brokers] would stand up and say, "OK, going down the Republican list, we ... [need] somebody to go in to see so-and-so and so-and-so and so-and-so," and companies would say, "I'll take him, I'll take her," or, "I'll organize a meeting and let everybody else know." And so this was the way we sort of coordinated our efforts. We had a meeting weekly with the legislative strategist and the business community to share information and ... so, it was really a sort of well-oiled machine. ...

We met with the White House on a regular basis.... Obviously, the White House can't ask us to do any lobbying activities, and I think some of the opponents of PNTR had put some pressure on the White House through Freedom of Information Act requests to find out when these meetings were held and what was being discussed and it was just pressure points . . . making sure that the White House knew that the folks on the Hill were well aware of what was going on and wanted to make sure that they didn't cross 

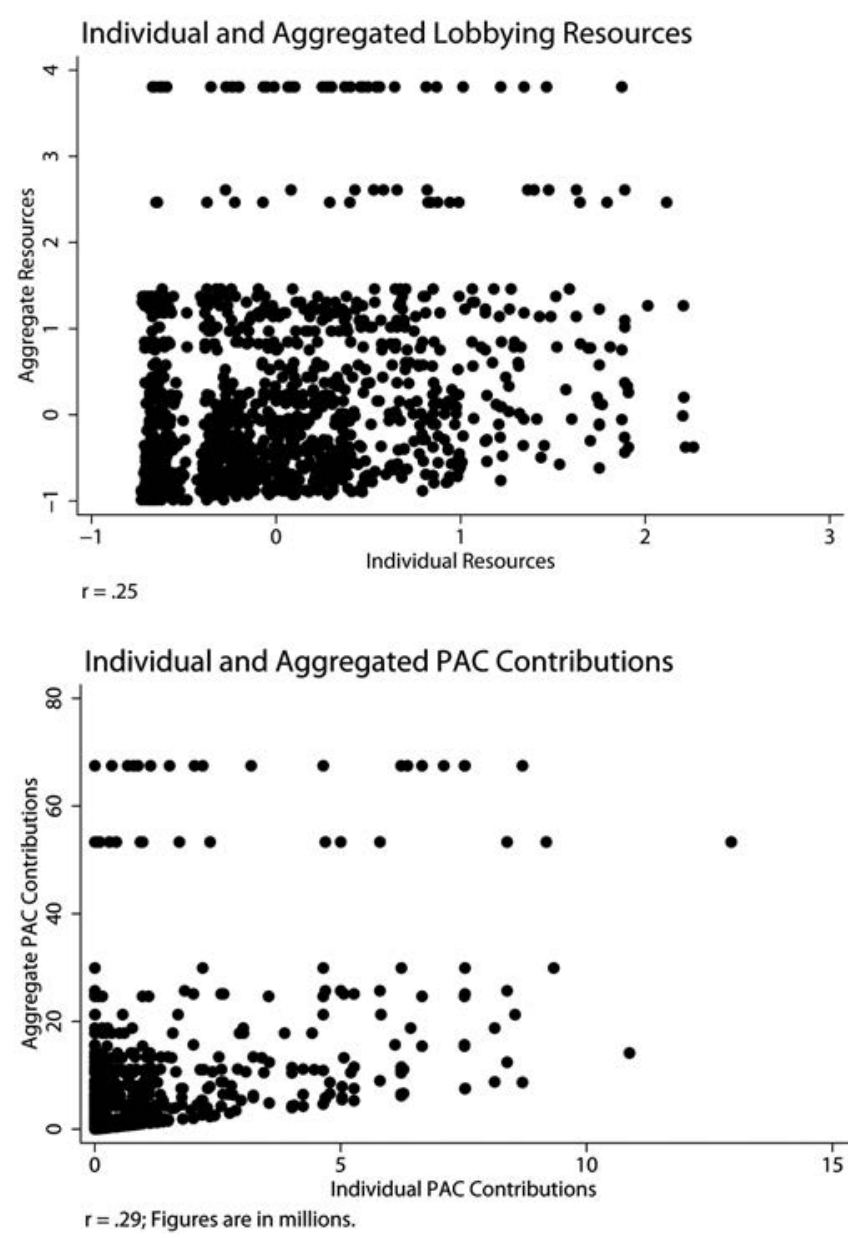

Figure 1. Aggregated lobbying resources mask great individual variation. The lower figure shows individual PAC contributions, in millions of dollars, over the four-year cycle for each of over 1,200 outside organizations in our sample compared to the aggregated PAC contributions for all members of the 214 actively lobbying sides. The upper figure shows the equivalent comparison for an index of lobbying resources. Individual resources are not strongly related to aggregate resources because lobbying sides include members with widely varying levels of resources.

the line. We're all a little sensitive-the White House is extremely sensitive to it. I mean, there's no secret. Yes, we shared information ... .

A legislative leader on the other side described virtually the identical process, though to his great displeasure he could not count the White House as an ally:

We would just run through a list [of members of Congress] and see who wants to take them. It's like homework assignments, except for yell out the name, and so-and-so says, "Yeah, I'll talk to them." Because either these people were from their area, or they have a personal relationship with them, and philosophically agree with them on some issues. ... And separately, we would at a staff level talk to the outside groups. We'd meet once a week with the key lobbyists from the labor unions, and from the Public Citizens, Global Trade Watch, and the environmental community, and the International Campaign for Tibet and what have you, and we would compare notes and see what they were hearing out in the field.

This congressional leader had a wide set of interest-group allies:

Friends of the Earth, an environmental group. . . . Sierra Club to some extent. They weren't doing as much whipping or activities as Friends of the Earth were, but they were involved and they were helpful. And International Campaign for Tibet as well. . . . They never had gotten involved in trade issues before, but Tibet is a huge thing for them, and they had a lot of activists. It's one of those sexy issues, Tibet is, and they can do these concerts where they get all these kids to show up for it and they had Goldie Hawn who came, and they have a lot of star power that supports their cause [and] ... who doesn't like the Dalai Lama?

This congressional leader ruefully notes his lack of access to the White House on this issue, however, and makes clear that it can be a powerful tool indeed:

The one thing that we can't offer that the White House can are other-I don't want to make this sound like it's illegal because it's not-but clearly they may have other interests with the administration as well. Like a road project or a particular bill and the administration is going to be able to work a little closer with them on that...

A legislative staffer to a member of Congress leading a fight to maintain abortion rights said simply: "We worked with the pro-choice groups every day." In sum, groups are part of the congressional whipping process. If they are extremely fortunate, they may have the White House agreeing to trade budget or policy advantages on other issues in order to gain particular congressional votes. If unlucky, they may face a powerful White House actively engaged on the other side.

PREDICTING THE NUMBER OF GOVERNMENT ALLIES We know from our qualitative understanding of the cases that are at the heart of this analysis that groups are at times 
working in well-organized sides and at other times working in parallel with other groups that seek the same goal; on rare occasions, they work alone. From the descriptive data, we have established that the resources an entire side can bring to bear in a political battle are much more significant than the resources of any lone lobbying group. The question now is the relative effect of interest-group resources from any individual actor, the collective resources of a side, and the characteristics of the issue on the mobilization of governmental allies.

We expect the aggregated resources of a side to matter more than the resources of individual advocates in explaining mobilization, and in this section, we test this idea empirically. The dependent variable is the number of government allies an advocate has on its side (the descriptive statistics for this indicator can be found in Table 1). The individual-level group resources include: (1) whether the advocate was lobbying through an in-house lobbyist; (2) whether the advocate had hired a lobbying firm to advocate on their behalf; (3) the number of former government officials a group had on its staff; (4) the group's total lobbying expenditure for the election cycle; and (5) their total PAC contributions for the election cycle. ${ }^{2}$

To consider the collective resources of the advocate's side, we aggregate each of these factors across all members of the side and then create an index through a factor analysis. ${ }^{3}$ The stronger the collective side is, we hypothesize, the more policymakers will be driven to mobilize to support the position. In addition to monetary and staff resources, another critical resource a side can possess is the support of key power players. To assess the effect of influential friends on the ability to mobilize even more allies within government, we include in the model whether the side included the White House, a high-level executive official, the Republican leadership in Congress or the Democratic leadership in Congress. High-level allies such as these can mo-

2. Total PAC donations and soft-money donations given by the advocate to both parties for the election cycle prior to and concurrent with the Congress in which the issue was identified. Therefore, an issue that we began following in the 106th Congress would have total PAC and softmoney contributions for the 1997-98 and 1999-2000 election cycles. An issue we began in the 107 th Congress would have the total contributions for the 1999-2000 and 2001-2002 election cycles.

3. All of the composite variables load highly on the first factor, with loadings ranging from .78 to .93 . We did not make an index for the individual actors because of missing data problems and very large numbers of zeros for particular indicators for individual groups. When we aggregate by side, these problems are resolved. The index consists of the standardized (mean $=0$, standard deviation $=1$ ) value resulting from the factor analysis of the five individual items listed in the previous paragraph. bilize even more allies, as they sense either victory or a very significant political issue that cannot be ignored.

Two additional variables relate to the side: its intent, and the number of government officials mobilized in opposition. Intent refers to whether the side seeks to maintain or to change the status quo, and we expect that efforts to change the status quo will generate more support than efforts to maintain. This is because it is generally easier to maintain than to change. If an official wants to see the status quo maintained, they have inertia on their side and may presume they do not need to mobilize to protect it. For those efforts at change to be successful, they must mobilize a larger cadre of government officials on their behalf. The number of government officials opposed is an important consideration to potential allies for obvious reasons: a large opposition signals an important and potentially costly political battle. We use this rather than the collective material resources of the opposing side because we think that the value of the resources is to attract government allies, so if the number of allies is more directly relevant. Of course, the two variables are highly correlated.

Finally, we include characteristics about the issue on which the advocates are lobbying: salience and partisanship. Salience of the issue is measured as the number of news articles on the issue in the major U.S. papers during the Congress the issue was being actively debated (collected through Lexis-Nexis searchers based on keywords established by the lead researcher on the issue that carried out the in-depth interviews). Partisanship is measured as to whether the issue was described as partisan by at least one advocate $(1=$ yes, $0=$ no). One could expect that elected officials would feel compelled to be involved in issues that have taken on partisan overtones. Table 2 shows the results.

Table 2 shows our model predicting the number of governmental allies. ${ }^{4}$ As the table presents the results of a ZINB

4. Table 2 shows a Zero-Inflated Negative Binomial model, which is appropriate because we have an inflated number of zeros: sides with no government allies at all. We cluster the standard errors by side, which controls for the fact that members of the same side have many characteristics in common. In the supporting information, we show alternative specifications of this model, demonstrating that it is highly robust to various specifications. Note that we do not present a hierarchical linear model (HLM) because the structure of our data. All members of the same side except government officials receive the same score on the key dependent variable: how many government allies they share. This makes it impossible to view the process in an HLM framework as there is so little independent variation within sides. Conceptually, this reaffirms our analysis showing that individual-level variables cannot possibly explain the variation in ability to recruit government allies once side-level variables are accounted for. The ZINB model we use, clustered by side, allows us to demonstrate these relations with accuracy. 
212 / Partners in Advocacy Christine Mahoney and Frank R. Baumgartner

Table 2. Gaining Government Allies

\begin{tabular}{|c|c|c|c|c|}
\hline Variable & Incident Rate Ratio & Robust SE & $z$ & $\operatorname{Prob}(z)$ \\
\hline \multicolumn{5}{|l|}{ Logit Model Predicting No Allies } \\
\hline Government actor & -1.63 & 0.53 & -3.08 & .002 \\
\hline In-house lobbyist & -1.63 & 1.14 & -1.43 & .154 \\
\hline Hired lobbyist & 0.82 & 0.72 & 1.14 & .254 \\
\hline Lobbying expenditures (millions) & 0.72 & 0.49 & 1.47 & .141 \\
\hline Covered officials* & 0.44 & 0.34 & 1.28 & .201 \\
\hline PAC spending (millions) & -0.26 & 0.30 & -0.85 & .394 \\
\hline Aggregate resource index & -6.98 & 3.15 & -2.21 & .027 \\
\hline Total opposition & -1.02 & 1.05 & -0.97 & .331 \\
\hline Change status quo & -2.86 & 0.95 & -3.01 & .003 \\
\hline News (x 100) & -0.84 & 0.49 & -1.71 & .087 \\
\hline Partisan & 0.14 & 0.71 & 0.20 & .841 \\
\hline Constant & -3.68 & 2.4 & -1.53 & .125 \\
\hline \multicolumn{5}{|c|}{ Count Model Predicting Number of Allies } \\
\hline In-house lobbyist & 0.97 & 0.04 & -0.66 & .506 \\
\hline Hired lobbyist & 0.90 & 0.05 & -2.04 & .041 \\
\hline Lobbying expenditures (millions) & 0.98 & 0.02 & -1.39 & .166 \\
\hline Covered officials ${ }^{\star}$ & 0.99 & 0.02 & -0.30 & .760 \\
\hline PAC spending (millions) & 0.98 & 0.02 & -1.05 & .293 \\
\hline Aggregate resource index & 1.30 & 0.10 & 3.45 & .001 \\
\hline Total opposition & 1.01 & 0.10 & 1.06 & .288 \\
\hline Change status quo & 1.16 & 0.16 & 1.05 & .295 \\
\hline White House support & 1.77 & 0.34 & 2.98 & .003 \\
\hline Executive support & 1.17 & 0.16 & 1.14 & .253 \\
\hline Republican leadership & 1.25 & 0.19 & 1.47 & .143 \\
\hline Democratic leadership & 1.71 & 0.13 & 3.99 & .000 \\
\hline News (x 100) & 0.88 & 0.04 & -3.07 & .002 \\
\hline Partisan & 1.03 & 0.15 & 0.22 & .824 \\
\hline Pseudo-log likelihood & -5699 & $($ prob $<.0000)$ & & \\
\hline Wald Chi-sq & 103.19 & $($ prob $<.0000)$ & & \\
\hline $\mathrm{N}$ & 2221 & & & \\
\hline
\end{tabular}

Note-Standard errors are clustered by side. Joint significance test for the five individual-level variables: chi-squared $=17.38$; Prob $>$ chi-squared $=0.07$.

* Covered officials indicates the number of recently employed government officials listed in the Lobby Disclosure Reports as lobbying on behalf of the client.

model, there are two parts. The first part shows the impact of the variable in question on the likelihood of having no government allies. Negative coefficients are therefore related with more allies. We present incident rate ratios (IRRs), so can be interpreted as percentage movements from 1.00; .98 would mean $2 \%$ less likely; 1.3 would mean $30 \%$ more likely, and so on. Here, we see that being a government official, having large material resources associated with the side, and seeking to change the status quo are significant predictors of having at least one government ally. The coeffi- cient for aggregate resources indicates almost a 700\% reduction in the likelihood of having no allies.

The outcome model, estimating the number of allies, is shown below the line. Again, the aggregate resource index plays a major role, with a $30 \%$ increase in allies for each point movement on the index; we also see that White House support is a major predictor (having White House support leads to $77 \%$ more allies, on average), as is having the Democratic leadership in Congress (which is associated with $71 \%$ more allies). The presence of paid lobbyists has a statistically 
significant and negative relationship with the number of allies. On average, groups with paid lobbyists have $10 \%$ fewer allies than do groups without paid lobbyists. This may be because continuing lobbying efforts are typically undertaken in-house, with outside lobbyists being called in only in times of trouble. In any case, we show a significant negative impact for hired lobbyists. Our measure of media salience is also significant, suggesting a $12 \%$ decline in government allies for every 100 news stories.

With the exception of being a government official (as opposed to an outside interest group), which is related to having more government allies, and the negative impact of hired as opposed to in-house lobbyists, none of the individuallevel resource measures is significant in either part of the model. Neither PAC contributions, lobbying expenditures, nor high-level (covered) lobbyists has any systematic relationship with the key cause of lobbying success: gaining government allies. (These variables also fail to reach statistical significance when considered as a group, rather than individually.) Similarly, partisanship, news coverage, and even the number of government officials mobilized in opposition are not strongly related to the mobilization of government officials in a policy dispute. The reasons for this should be clear from Figure 1 above: individual lobbyists, with widely varying levels of resources, are embedded in highly heterogeneous lobbying sides.

Table 3 presents a model of the same process but where we analyze the 214 sides, not the 2,221 advocates as included in Table 2. Considering that individual resources matter little and that government officials appear to be looking at aggregate resources rather than at individuals, this may be the simplest presentation of our results. When we aggregate our data in this manner, there is no need for a zero-inflated model, so we present a Negative Binomial model, which can be interpreted in the same manner as the bottom half of Table 2. Again, we present IRR's, and in this case we cluster our standard errors by issue, rather than by side.

The results of Table 3 confirm those in Table 2. Significant predictors are aggregate resources, seeking to change the status quo, and the actions of leading government officials. News coverage is significant but has a marginal substantive impact. In all, we find powerful evidence that political scientists and journalists are barking up the wrong tree if they expect to find evidence of individual lobbying power on mobilizing government officials (or gaining the policy preferences that they want). Rather than building models about individual lobbyists, we need to think of the entire constellation of actors mobilized around a policy issue. That is clearly what important government officials are doing when they consider whether or not to invest their time, political capital, and reputations on this, rather than that, legislative priority.

We strongly support Hypothesis 1, which might be called the lobbying paradox hypothesis: individual resources do not matter. We also support Hypothesis 2-that wealthy sides do indeed enjoy considerable success in gaining government allies-and Hypothesis 3-that having particularly prominent government officials sends an important signal to others, inducing them to become involved as well. We find support for Hypothesis 4 about media salience, but

Table 3. Side-Level Predictors of Number of Government Allies

\begin{tabular}{lcrrr}
\hline \multicolumn{1}{c}{ Variable } & Incident Rate Ratio & Robust SE & $z$ & $\operatorname{Prob}(z)$ \\
\hline & & & & \\
Aggregate resource index & 1.463 & 0.126 & 4.42 & 0.000 \\
Total opposition & 1.022 & 0.018 & 1.23 & 0.217 \\
Change status quo & 1.291 & 0.186 & 1.77 & 0.077 \\
White House support & 1.772 & 0.336 & 3.02 & 0.003 \\
Executive support & 1.361 & 0.170 & 2.47 & 0.014 \\
Republican leadership & 1.848 & 0.265 & 4.28 & 0.000 \\
Democratic leadership & 1.957 & 0.256 & 5.13 & 0.000 \\
News (x 100) & 0.946 & 0.016 & -3.22 & 0.001 \\
Partisan & 1.038 & 0.151 & 0.26 & 0.796 \\
Pseudo log-likelihood & -499.42 & (prob < & & \\
Wald Chi-2 (9) & 124.34 & (prob $<.000)$ & & \\
N & 214 & & & \\
\hline
\end{tabular}

Note-Entries are the results of a negative binomial model predicting the number of government officials active, with robust standard errors clustered by issue. 
none for Hypothesis 5 about partisanship. What clearly matters in the search for government officials is the creation of a powerful lobbying side. Success then generates more success, as the willingness of a major government official, such as the White House or the congressional party leadership, to associate themselves publicly with the cause tells others that this train is leaving the station. In Washington, that matters.

\section{LOBBYISTS, LIKE WOLVES, WORK IN PACKS}

The wealthy do indeed get what they need in Washington. But we have to look in the right place in order to find this impact. Rather than pick an individual lobbying organization and count up its resources, we need to recognize that lobbyists, like wolves, work in packs. Lone wolves are no more successful in Washington than they are in nature, and in any case there are few of them. The route to success in Washington is to mobilize a large and diverse group of actors to support a shared policy goal. Often, the motivations may be quite diverse; after all, complicated federal policies may affect many different constituencies in many different ways. In a previous book based on the same data collection as that reported here, the authors showed that government allies are a key determinant of policy success (Baumgartner et al. 2009). Here, our focus has been on the obvious next question: how to mobilize government allies. Government actors, thinking about where to invest their resources, may well want to help an individual group. But before leading the charge, they take a careful look at the full range of who is involved. Given the highly networked and close relations among DC lobbyists and policy makers, the last place where we should be looking for an explanation of lobbying success is in the actions of any single group. They simply do not act alone. And government officials clearly respond by taking the lead on those issues where the strongest are already pushing the hardest.

\section{ACKNOWLEDGEMENT}

We would like to thank our collaborators Jeff Berry, Marie Hojnacki, David Kimball, and Beth Leech as well as Tim LaPira and the many students already acknowledged in other publications for their help in making this research project possible and for allowing us the freedom separately to publish these results, which draw from our collective project. Mel Atkinson provided important research assistance and statistical consulting.

\section{REFERENCES}

Aberbach, Joel D., Robert D. Putnam, and Bert A. Rockman. 1981. Bureaucrats and Politicians in Western Europe. Cambridge, MA: Harvard University Press.
Ainsworth, Scott H. 1993. "Regulating Lobbyists and Interest Group Influence." Journal of Politics 55 (1): 41-56.

Ainsworth, Scott H. 1997. "The Role of Legislators in the Determination of Interest Group Influence.” Legislative Studies Quarterly 22 (4): 517-33.

Austen-Smith, David. 1993. "Information and Influence: Lobbying for Agendas and Votes.” American Journal of Political Science 37 (3): 799833.

Austen-Smith, David, and John R. Wright. 1994. "Counteractive Lobbying." American Journal of Political Science 38 (1): 25-44.

Banaszak, Lee Ann. 2010. The Women's Movement Inside and Outside the State. New York: Cambridge University Press.

Bauer, Raymond A., Ithiel de Sola Pool, and Lewis A. Dexter. 1963. American Business and Public Policy: The Politics of Foreign Trade. New York: Atherton Press.

Baumgartner, Frank R., Jeffrey M. Berry, Marie Hojnacki, David C. Kimball, and Beth L. Leech. 2009. Lobbying and Policy Change: Who Wins, Who Loses, and Why. Chicago: University of Chicago Press.

Baumgartner, Frank R., and Beth L. Leech. 1998. Basic Interests: The Importance of Groups in Politics and in Political Science. Princeton, NJ: Princeton University Press.

Baumgartner, Frank R., and Beth L. Leech. 2001. "Issue Niches and Policy Bandwagons: Patterns of Interest Group Involvement in National Politics.” Journal of Politics 63 (4): 1191-1213.

Becker, Gary S. 1983. "A Theory of Competition among Pressure Groups for Political Influence.” Quarterly Journal of Economics 98 (3): 371-400.

Bendor, Jonathan, and Terry M. Moe. 1985. "An Adaptive Model of Bureaucratic Politics.” American Political Science Review 79 (3): 755-74.

Bentley, Arthur F. 1908. The Process of Government. Chicago: University of Chicago Press.

Carpenter, Daniel P., Kevin M. Esterling, and David M. Lazer. 1998. "The Strength of Weak Ties in Lobbying Networks.” Journal of Theoretical Politics 10 (4): 417-44.

Cater, Douglass. 1964. Power in Washington. New York: Random House.

DeGregorio, Christine A. 1997. Networks of Champions: Leadership, Access, and Advocacy in the U.S. House of Representatives. Ann Arbor: University of Michigan Press.

Fenno, Richard F., Jr. 1973. Congressmen in Committees. Boston: Little, Brown.

Grenzke, Janet M. 1989. "PACs and the Congressional Supermarket: The Currency is Complex." American Journal of Political Science 33 (1): 1-24.

Hall, Richard L., and Alan V. Deardorff. 2006. "Lobbying as Legislative Subsidy." American Political Science Review 100 (1): 69-84.

Heaney, Michael T., and Geoffrey M. Lorenz. 2013. "Coalition Portfolios and Interest Group Influence over the Policy Process.” Interest Groups and Advocacy 2 (3): 251-77.

Heclo, Hugh. 1978. "Issue Networks and the Executive Establishment." In The New American Political System, ed. Anthony King. Washington, DC: American Enterprise Institute, 87-124.

Heinz, John P., Edward O. Laumann, Robert L. Nelson, and Robert H. Salisbury. 1993. The Hollow Core: Private Interests in National Policymaking. Cambridge, MA: Harvard University Press.

Kingdon, John W. 1989. Congressmen's Voting Decisions. $3^{\text {rd }}$ ed. Ann Arbor: University of Michigan Press.

Kingdon, John W. 1995. Agendas, Alternatives, and Public Policies. $2^{\text {nd }}$ ed. New York: Harper Collins.

Kollman, Ken. 1998. Outside Lobbying: Public Opinion and Interest Group Strategies. Princeton, NJ: Princeton University Press.

Laumann, Edward O., and David Knoke. 1987. The Organizational State: Social Choice in National Policy Domains. Madison: University of Wisconsin Press. 
Leech, Beth L., and Frank R. Baumgartner 1998. "Lobbying Friends and Foes in Washington." In Interest Group Politics (5th ed.), eds. Allan J. Cigler and Burdett A. Loomis. Washington, DC: Congressional Quarterly, 217-33.

Mahoney, Christine. 2008. Brussels vs. the Beltway: Advocacy in the United States and the European Union. Washington, DC: Georgetown University Press.

Mayhew, David. 1974. Congress: The Electoral Connection. New Haven, CT: Yale University Press.

Mayhew, David R. 1991. Divided We Govern. New Haven, CT: Yale University Press.

Price, David E. 1978. Policymaking in Congressional Committees: The Impact of Environmental Factors. Tucson: University of Arizona Press.
Redford, Emmette S. 1969. Democracy in the Administrative State. New York: Oxford University Press.

Sabatier, Paul A. 1988. "An Advocacy Coalition Framework of Policy Change and the Role of Policy-Oriented Learning Therein." Policy Sciences 21 (2/3): 129-68.

Smith, Richard A. 1995. "Interest Group Influence in the U.S. Congress." Legislative Studies Quarterly 20 (1): 89-139.

Wright, John R. 1985. "PACs, Contributions, and Roll Calls: An Organizational Perspective." American Political Science Review 79 (2): 40014 .

Wright, John R. 1990. "Contributions, Lobbying, and Committee Voting in the U.S. House of Representatives." American Political Science Review 84 (2): 417-38. 